\title{
Articles
}

\section{LESSONS FROM THE CZECH AND SLOVAK ECONOMIES SPLIT}

\author{
Růžena Vintrová*
}

\begin{abstract}
The less developed Slovak economy was converging quickly to the Czech economic level after the World War II, thanks to the massive reallocation of resources. The inflow amounted to $11 \%$ of the Slovak GDP, the outflow from the Czech Lands represented $4 \%$ of their GDP. The Slovak GDP per capita reached around three quarters of the Czech one in 1992. After the split of Czechoslovakia, the economic policy adjusted to the changed conditions by sinking real wages and depreciation of Slovak koruna, so that the Slovak ULC are the lowest among the Central European countries now. The cost competitiveness, accompanied by an abundant inflow of FDI and economic reforms after the EU accession helped to speed the real convergence. As a result, the Slovak GDP per capita reached $84 \%$ of the Czech one in 2007 . The balance of costs and benefits of the euro adoption varies due to different conditions in the succession states and to a certain extent justifies the more rapid advancement to the single currency in Slovakia. The common challenge for both economies is to overcome the one-sided orientation on cost/price competitiveness based on low wages.
\end{abstract}

Keywords: regional reallocation of resources, real and nominal convergence, real gross domestic income, price and wage level convergence, costs and benefits of euro adoption.

JEL Classification: E31, F15, F43, O11

\section{Introduction}

Since the founding of a separate Czechoslovak state in the year 1918, Czech and Slovak economies were being formed as one integrated whole. In the period between the wars, their development took place in market conditions of small open economies, strongly dependent on upheavals in the outside environment. Until the end of the 1920s, impres-

* Centre for Economic Studies, University of Economics and Management, Prague

(ruzena.vintrova@vsem.cz).

The paper was written with the support of grants from the Czech Science Foundation (GAČR)

GA402/08/1798 and the Ministry of Education, Youth and Sports (MŠMT), Centrum výzkumu konkurenční schopnosti české ekonomiky $1 \mathrm{M} 0524$. 
sive economic growth set in, involving mainly the industrially developed Czech Lands. The great crisis in the 1930s, which broke forth with a delay in Czechoslovakia, was particularly devastating and lengthy here. It had the most disruptive effect on the poor regions, which included Slovakia and as well as a large part of the Czech borderland territory, inhabited by the Sudetten Germans. During the World War II, the two economies were temporarily separated. The imperial German protectorate was declared over the enemy-held Czech Lands, with their borderland curtailed, and Slovakia became a formally independent satellite state of Hitler's Germany.

After the renewal of Czechoslovakia within its pre-war borders (without Subcarpatian Russia) its inclusion into the autarchic Eastern Block led to a general economic backwardness. Modernisation slowed down, and a considerable descent in the world chart of economic level took place. The more favourable aspects of this period include fast progress in balancing the economic levels of the two parts of the country. Central planning and all-society ownership enabled extensive transfer of resources from the Czech Lands to Slovakia, financing major investments in industry and infrastructure. The progress in economic levelling was being achieved, while simultaneously deforming the structure of production, focusing on the heavy industry, which found markets in countries behind the Iron Curtain. For this reason, the structural problems in both successor states of the former Czechoslovakia during the transfer to market economy after the dissolution of the eastern markets were greater than in the other post-communist Central European countries. Slovakia was affected particularly heavily. The division of the common state in the early transformation period at the beginning of the year 1993 represented an additional economic shock. It demanded a one-shot lowering of the living standard of citizens in Slovakia in relation to the Czech Republic and a generally more flexible adjustment to new economic conditions. The different initial economic levels called for different economic policies in the two successor member states.

Studying practical experience at longer temporal distance provides empirical material for testing the findings of economic theory, relating to integration and disintegration processes in regions with different economic levels. A reverse example can be seen in the reunification of economically less developed Eastern Germany with the more developed Western Federal Lands. Comparing the findings from these two extremely different examples of post-communist development enables us to examine the efficiency of diverse approaches to economic policy and their effects on competitive ability. In wider international context, all of these processes were being influenced by an inclusion of the transforming countries into European integration, both prior to and after their accession to the European Union.

This paper follows the development prior to the dissolution of Czechoslovakia and the convergence of the economic level of the two successor countries in the past 15 years. The individual factors, influencing economic development in the post-communist countries, underwent turbulent development in the periods of sweeping institutional changes. It is difficult to render a precise description and separation of their impor- 
tance. The following attempt starts from an analysis of the macroeconomic context, based mainly on the statistics of national accounts. ${ }^{1}$

\section{The Convergence of the Slovak Economy in the Common State}

\section{The fast narrowing of the Slovak economic gap after the World War II}

The rate of economic growth in Slovakia in the first post-war decade reached two-digit levels and far exceeded the growth both in Czech Lands and in the most of other regions in Europe and worldwide. Net national income (NNI) in the years 1949 to 1989 posted a real 11 fold increase in Slovakia, while in the Czech Lands it was a 6 fold increase. ${ }^{2}$ With the time flow, the annual rates of increase slowed down from $10 \%$ in Slovakia and less than $8 \%$ in the Czech Lands in the years 1948-1960 to a rate of approximately 5.5\% and $4.0 \%$, respectively, in the following two decades. In the $1980 \mathrm{~s}$, there was a dive to a mere $2.6 \%$ in Slovakia and $1.5 \%$ in the Czech Lands (see Table 1).

Table 1

Net National Income of the Czech Lands and Slovakia 1949-1989 (in \%, constant prices)

\begin{tabular}{|l|c|c|c|c|c|}
\hline & $\mathbf{1 9 6 0 / 1 9 4 8}$ & $\mathbf{1 9 7 0 / 1 9 6 0}$ & $\mathbf{1 9 8 0 / 1 9 7 0}$ & $\mathbf{1 9 8 9 / 1 9 8 0}$ & $\mathbf{1 9 8 9 / 1 9 4 8}$ \\
\hline $\begin{array}{l}\text { Czech Lands } \\
\text { NNI total - index per period }\end{array}$ & 245 & 148 & 148 & 115 & 614 \\
\hline - annual average & 7.7 & 4.0 & 4.0 & 1.5 & 4.5 \\
\hline NNI per capita - index per period & 225 & 146 & 140 & 114 & 527 \\
\hline - annual average & 7.0 & 3.2 & 2.8 & 1.1 & 4.1 \\
\hline Slovakia & & & & & \\
NNI total - index per period & 311 & 172 & 166 & 126 & 1,120 \\
\hline - annual average & 9.9 & 5.6 & 5.2 & 2.6 & 6.1 \\
\hline NNI per capita - index per period & 269 & 152 & 150 & 119 & 732 \\
\hline - annual average & 8.6 & 3.5 & 3.5 & 1.5 & 5.0 \\
\hline
\end{tabular}

Source: Own calculations on the basis of FSU (1985) and FSU, CSU and SSU (1992).

1 The numerical data drew on the statistics of the national accounting of the Czech Statistical Office (CSU), the Slovak Statistical Office (SSU), Eurostat and the OECD. The period before November 1989 is documented according to the available data from the balances of national economy, compiled in the period of central planning, which were originally kept top secret. The basic data from them were partially published in the Historical Statistical Yearbook of Czechoslovakia (Historická statistická ročenka ČSSR, FSU, 1985) and the consequential yearbooks of CSU and SSU from the years 1986 to 1990. After the year 1989, the detailed balance arrangements from the FSU database were declassified, too. A comparison of various types of indicators from the balances of national economy and national accounts (according to the systems SNA and ESA respectively) can only be carried out by using complex transition bridges. The conversions used the methodical comparative studies of the Conference of European Statisticians at the UN in Geneva, which focused on comparing the systems of national economic balances and national accounts intensively at the end of the 1950s and in the course of the 1960s.

2 The NNI indicator, used in the period of central planning, differed from the currently used gross domestic product (GDP) in that it only included the so-called production fields (that is without the so-called non-productive services), and also in the fact that amortisation of fixed capital was excluded from it. 
The economic advancement of Slovakia was connected with a dynamic population development. The number of citizens increased from 3.4 million in the year 1948 to as many as 5.3 million people in the year 1989, i.e. by 53\%. In the Czech Lands, the growth in the number of citizens was much slower - there was an increase from 8.9 million people to 10.4 million, i.e. by $16 \%$. For that reason, the growth of national income per capita differed less in the two parts than the growth of the summary economic performance. In the monitored period, this indicator increased by 7.3times in Slovakia and 5.3 times in the Czech Lands.

In the second half of the $20^{\text {th }}$ century, one could hardly find a parallel of such fast-progressing equalisation of the economic level of a weaker region with the more developed within one common state. In relation to the Czech Lands, the posted national income of Slovakia per capita increased from $60 \%$ in the year 1948 to $88 \%$ in the year 1989 (see Figure 1). ${ }^{3}$

Figure 1

Net National Income of Slovakia in Relation to the Czech Lands 1948-1989 (in \%, current prices) $^{1)}$

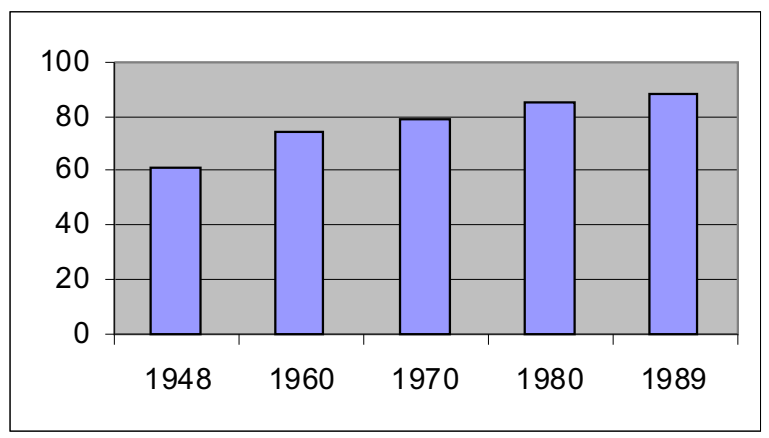

1) Without the foreign trade margin.

Source: Statistical Yearbooks of the FSU, CSU and SSU, various years, own calculations.

In an international chart of economic level, GDP per capita in purchasing power parity in Slovakia was higher than in Hungary at the turn of the 1980s and 1990s, and considerably higher than in Poland (see Figure 2).

3 GDP shows a lower proportion of Slovakia in the all-nation total than NNI, which results from a higher proportion of non-production services and fixed capital stocks in the Czech Lands. The difference in GDP per capita between Slovakia and the Czech Lands would have been approximately 3 to 4 percentage points higher at the end of the 1980s than according to NNI. Another distorting factor was the planned prices, which were of the cost type and thus did not reflect the lower productivity of labour in Slovakia at that time. Unlike the hypothetical market prices, they exaggerated the proportion of SR to CR. For these reasons, the NNI indicator is rather comparable in a time series, while it is better to use the now common GDP indicator for a characteristic of the achieved level. 
Figure 2

GDP per capita of Slovakia in Relation to the Czech Republic, Hungary and Poland $(=100)$ in 1990 (current purchasing power parities)

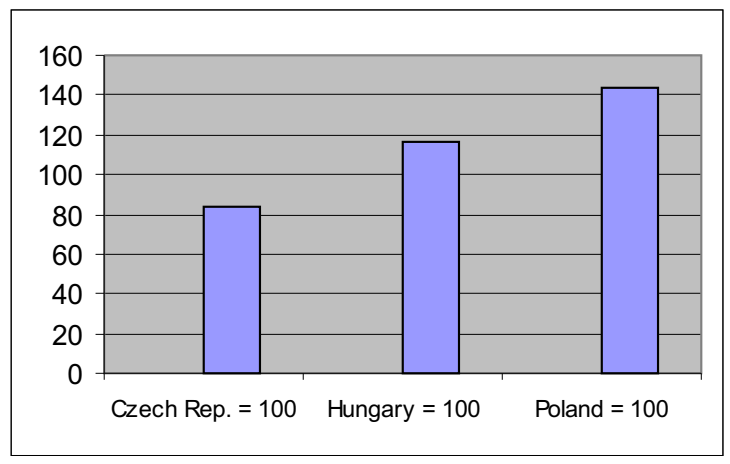

Source: ECP’90, Auer, Müller (1993).

The harder effects of the transformation crisis when transferring to market economy led to a widening of the gap in economic level in Slovakia. Just before the division of Czechoslovakia, the economic level dropped to approximately three quarters of the Czech economic level there. By combining data from statistical yearbooks, GDP per capita in the year 1992 in the Slovak Republic can be estimated as 58,000 Czechoslovak korunas compared to 77,000 Czechoslovak korunas in the Czech Republic. In the indicator of the labour productivity, measured as the GDP per person employed, the difference was smaller, representing only approximately 11 percentage points (see Table 2).

Table 2

The Economic Level and Its Factors in the Czech Lands and in Slovakia, 1992

\begin{tabular}{|c|c|c|c|}
\hline & Czech Lands & Slovakia & $\mathbf{C L}=\mathbf{1 0 0}$ \\
\hline GDP per capita in thousands CSK $^{1)}$ & 76.7 & 58.1 & 75.8 \\
\hline GDP per person employed in thousands CSK $^{1)}$ & 160.5 & 142.6 & 88.8 \\
\hline Participation rate in $\%{ }^{2)}$ & 47.7 & 40.7 & 85.4 \\
\hline Average monthly wages in CSK & 4,667 & 4519 & 96.8 \\
\hline
\end{tabular}

1) Current prices; 2) The number of employed persons (annual average) to the total population (annual average). Source: FSU, CSU, SSU (1992); CSU (1993); SSU (1993); OECD (1994); own calculations.

\section{Transfer of resources from the Czech Lands}

The transfer of resources from Czech Lands, used for massive greenfield construction, was the main source for the economic level's fast growth in Slovakia. A common state with integrated economy is able to concentrate and make purposeful redistribution of resources for building transport and other infrastructure and for support of the educational system and research. It has a number of tools available to support a removal of the gap in economic level in the stagnant regions. In centrally planned economy, moreover, direct command tools also existed for dividing investment in industry and 
other fields of production, which were being used when building new and reconstruction the existing state-run plants.

The private and public consumption fund in relation to the national income produced reached $86 \%$ to $88 \%$ in Slovakia (with an exception of the decade in the 1970 s, when it reached $79 \%$ ). The own resources for investment in development were very limited, so that extensive new construction had to be financed centrally for the most part. With the use of transfer, the accumulation fund ${ }^{4}$ had considerably higher proportion in national income used than in the Czech Lands. In the years 1949-1989, it reached an average of $25 \%$ in relation to $18 \%$ (see Table 3 ).

Table 3

The Share of the Accumulation Fund to the Net National Income Used in the Czech Lands and in Slovakia 1948-1989 (in \% of current prices)

\begin{tabular}{|l|c|c|c|c|c|}
\hline & $\mathbf{1 9 4 8 - 1 9 6 0}$ & $\mathbf{1 9 6 1 - 1 9 7 0}$ & $\mathbf{1 9 7 1 - 1 9 8 0}$ & $\mathbf{1 9 8 1 - 1 9 8 9}$ & $\mathbf{1 9 4 8 - 1 9 8 9}$ \\
\hline Czech Lands & 17.6 & 17.4 & 24.6 & 13.9 & 18.4 \\
\hline Slovakia & 22.0 & 25.6 & 29.9 & 20.5 & 24.6 \\
\hline
\end{tabular}

Source: FSU (1985); FSU, CSU a SSU (1992); own calculations.

Between the years 1948 and 1989, the outflow of resources from the Czech Lands to Slovakia reached $5 \%$ of Czech NNI, while the inflow to Slovakia represented $14 \%$ of the local NNI (see Table 4).

Table 4

The Transfer of Resources from the Czech Lands to Slovakia 1948-1989 (current prices)

\begin{tabular}{|l|c|c|c|c|c|c|}
\hline & $\mathbf{1 9 4 8 - 5 0}$ & $\mathbf{1 9 5 1 - 6 0}$ & $\mathbf{1 9 6 1 - 7 0}$ & $\mathbf{1 9 7 1 - 8 0}$ & $\mathbf{1 9 8 1 - 8 9}$ & $\mathbf{1 9 4 8 - 8 9}$ \\
\hline Bill. CSK & 6.3 & 43.9 & 83.7 & 152.2 & 175.8 & 461.9 \\
\hline $\begin{array}{l}\text { In \% to the } \\
\text { Czech NNI }\end{array}$ & 3.6 & 4.1 & 5.3 & 5.4 & 5.5 & 5.2 \\
\hline $\begin{array}{l}\text { In \% to the } \\
\text { Slovak NNI }\end{array}$ & 14.9 & 15.6 & 15.9 & 13.9 & 12.8 & 13.9 \\
\hline
\end{tabular}

Source: FSU, CSU a SSU (1992); own calculations (according the methodology described in Box 1).

In conversion to GDP, this analogically represented $4 \%$ and $11 \%$, respectively. ${ }^{5}$ It reached the maximum value in the first half of the 1950s, when the fast rates of economic growth enabled such spread. In the 1980s, the extent of outflow of resources from Czech economy began to exceed the GDP increases, which led to stagnating consumption and investments. This fact, among others, explains the stronger frustration of inhabitants in the Czech Lands compared to Slovakia in the pre-November period. It also sheds light on the willingness of a part of the Czech political elites to dissolve the common state in the critical period at the beginning of the 1990s.

4 The content of the accumulation fund consisted of new investments in basic funds after deduction of the amortization of existing funds plus the increase in stock, circulating funds and reserves.

5 The conversion in relation to GDP was based on the years 1985 to 1991, when the Czechoslovak statistics monitored both indicators simultaneously. 
The method of calculation of the transfer and the used statistical records are stated in Box 1. The national income produced and the national income used on the territory of the Czech Lands and Slovakia served as the starting indicators. The term "national" is somewhat misleading in this case, because the recorded indicators were monitored based on territorial principle and the transfers of income (losses or profits and wages) within the state were not recorded. Based on national principle, the national income produced would have been higher in the Slovak Republic, because more Slovak employees worked in the Czech Lands than vice versa.

\section{Box 1}

\section{The Methodology of the Transfer Calculation}

The balance of national economy (BNE) was the main statistical resource for the transfer between the two parts of the common state calculations. The balance of the gross social product and that of the net national income were constructed severally for each of the two parts of the common state. However, the total financial balance, which characterises the primary income division and the secondary redistribution of the financial resources, was constructed only at the common state level. Some of the key BNE data were unclassified in the Historical Statistical Yearbook of the Czechoslovak Socialist Republic (Historická statistická ročenka ČSSR) in 1985 at first. This yearbook contained the time series of the basic balance of gross social product and net national income indicators from 1948 to 1983 , according to the main production and use components. Beginning from 1984, analogical data were published in the current statistical yearbooks. (The foreign trade balance and margin were registered only at the common state level.)

On the balance identities basis, it was possible to find out the surplus of the Czech net national income produced over the net national income used, which covered the deficit of resources in Slovakia. The net national income produced (NNIP) on the common state level equals the net national income used (NNIU), which contains the consumption fund (private and public), accumulation (i.e. gross capital formation without amortisation), foreign trade balance (FTB), referred to as relations to abroad balance ${ }^{6}$ and losses (L). These relations are expressed by the following equation:

$$
\mathrm{NNIP}=\mathrm{NNIU}+\mathrm{FTB}+\mathrm{L}
$$

The sum of the NNIU for the two parts of the state, similarly to the sum of losses, was identical with the common state total. However, the summation of NNIP for the two parts of the state was not identical with the common state total with regard to undistributed foreign trade items. ${ }^{7}$ The undistributed FTB and the foreign trade margin as part of

6 The FTB calculation changed over time. Until the year 1965, the so-called balance of credit relations to abroad was being included into BNE. As of the year 1966, it was the balance of foreign trade in foreign prices, used in mutual payments. The so-called internal reproductive price adjustment (vnitřní reprodukční cenové vyrovnání, VRCV) was being calculated, which was kept top secret. The foreign trade margin, based on the difference between sales prices and purchase prices, was included in the production of national income in the foreign trade branch.

7 Converted data about NNIP are available in the 1993 Statistical Yearbook of the Czech Republic, including the sector of foreign trade, the net production of which reached CSK $30 \mathrm{bn}$ to CSK $40 \mathrm{bn}$ per year in the Czech Republic in the period from 1985 to 1991. 
production make it impossible to use the equation (1) in the single republics. To discover the difference given by the internal (intrastate) transfer, it is necessary to complete the two republics' NNIU, adding their hypothetical share on the FTB. This calculation was based on the conventional presumption of the FTB and foreign trade margin division according to the share of the individual republics on the $\mathrm{NNIP}^{\mathrm{pt}}$ (partly total), i.e. on the NNIP constructed as the sum of NNIP in the two republics. The calculation was based on the following formulas:

$$
\begin{gathered}
\mathrm{FTB}=\mathrm{NNIP}-\mathrm{NNIU}-\mathrm{L} \\
\mathrm{NNIP}^{\mathrm{pt}}=\sum \mathrm{NNIP}_{\mathrm{CZ}}+\mathrm{NNIP}_{\mathrm{SK}} \\
\mathrm{FTB}_{\mathrm{CZ}}=\mathrm{FTB} * \mathrm{NNIP}_{\mathrm{CZ}} / \mathrm{NNIP}^{\mathrm{pt}} \\
\mathrm{FTB}_{\mathrm{SK}}=\mathrm{FTB} * \mathrm{NNIP}_{\mathrm{SK}} / \mathrm{NNIP}^{\mathrm{pt}}
\end{gathered}
$$

The transfer (T) was enumerated as the difference between the NNIP in the individual republic and the sum of its NNIU (i.e. consumption and accumulation), losses and the share on the common state FTB.

$$
\begin{aligned}
& \mathrm{T}_{\mathrm{SK}}=\mathrm{NNIP}_{\mathrm{SK}}-\mathrm{NNIU}_{\mathrm{SK}}-\mathrm{L}_{\mathrm{SK}}-\mathrm{FTB}_{\mathrm{SK}} \\
& \mathrm{T}_{\mathrm{CZ}}=\mathrm{NNIP}_{\mathrm{CZ}}-\mathrm{NNIU}_{\mathrm{CZ}}-\mathrm{L}_{\mathrm{CZ}}-\mathrm{FTB}_{\mathrm{CZ}}
\end{aligned}
$$

The resulting transfer was always positive in the Czech Republic and negative in Slovakia.

There is also a technical problem, which burdens the method of calculation. This is because only the statewide balance was being equilibrated. Statistical discrepancies may be concealed within the differences between the national income produced and its use in the individual republics. For this reason, the calculations for the individual years need to be seen as merely rough orientation. ${ }^{8}$ Balance deviations can be expected to equilibrate partially in a longer time series, so that the informative value of this indicator for a longer period gradually increases.

The extent of transfer in international scope represented wide redistribution of sources. For comparison it can be said that the existing transfers from the structural and other funds within the European Union reach an inflow of only approximately $2 \%$ of GDP in long-term average in the countries, which are catching up. The burden on Czech economy ensuing from redistribution was approximately the same that the old federal states of Germany now feel, contributing 4\% of GDP, too, towards the development of the new Federal Lands. ${ }^{9}$ Given the difference in economic strength between the two parts of Germany, this inflow represents from one fifth to one quarter of the new Federal Lands' GDP.

The negative side of extensive redistribution typical for centrally planned economy of the former Czechoslovakia were the deformations of production structure, resulting from the autarkic development within countries of the Council for Mutual Economic

8 Another form of estimate, based on an analysis of financial flow in public budgets and other redistribution channels, which was carried out by government economists before the dissolution of the common state, provided not very different results.

9 The data taken over from a report of the government commission of 13 experts, led by Klaus von Dohnanyi from the year 2004, see Berg., S. et al. (2004), p. 26. 
Assistance. Extensive new "greenfield" construction led to the development of gigantic plants of the profiling sectors (metallurgy, armament industry, etc.), the development of small and medium companies lagging behind and the modernisation of production in other fields being delayed. The transfer to market economy in the 1990s fully revealed the risks of one-sided development of production structure.

\section{The Development of the Czech and Slovak Republics after the Split}

\section{The transformation crisis, adjustment of economic policies and restructuring of production}

The transformation crisis, which was brought about by the transfer to market economy, had an especially strong effect on the Czechoslovak economy with its overrated heavy industry tied to markets in countries of the Eastern Block. In order to achieve competitive ability on Western markets, it was necessary to considerably reduce prices and wages in relation to foreign countries. For this purpose, a fierce depreciation of the Czechoslovak koruna took place in the course of the year 1990, carried out in three steps.

In Slovakia, where gigantic heavy industry plants and strong armament production had been established, the collapse of the Eastern markets had even more profound after-effects. In the market conditions, the redistribution of financial resources within the state changed its form and abated considerably. The directive tools for redistribution seceded completely. Slovak banks had to borrow relatively more from the central funds, because the savings were much lower in Slovakia than in the Czech Lands. ${ }^{10}$

There was an increase of tension and revived disputes in the political life, known as "who is the worse for whom". In the common state, labour as well as the capital factor moved freely, which was being used for purpose-oriented arguments. On the Czech side, great transfer of public resources to Slovakia was being pointed out, while on the Slovak part, greater participation of Slovak workers in the creation of GDP on Czech territory was pointed out, etc. The disputes and tug-of-war relating to common resources drew attention away from the more important common problems, such as the stimuli and motivation towards raising economic performance during the transfer from central planning to market economy. The division of the common state intensified the responsibility for the own development of individual republics. From this perspective, it can be retrospectively seen as beneficial.

The differing conditions enforced an adjustment of economic policies. The weaker Slovak economy demanded greater restriction in wages and greater currency depreciation than Czech economy did. Only with a relative reduction of costs compared to foreign countries was it possible to ensure competitive prices in export and to stand the test of international exchange. In the initial transformation period, GDP generation in Slovakia was considerably lower than consumption and investments in relation to

10 The "soft" loans provided by banks began to cause problems with pay off. During the dissolution of the common state, the relatively high borrowings of commercial banks operating in Slovakia represented a claim of the Czech side, which the Slovak side considered disputable. 
other countries. In the year 1990, Slovak GDP per capita reached $84 \%$ of the level in the Czech Republic, while the use of resources (the sum of households and public consumption and of the gross capital formation) was considerably higher due to the transfer, reaching $91 \%$ per capita (see Vintrová 2006 , p. 41 ).

The cost competitiveness of the Slovak economy increased, when a $10 \%$ one-off depreciation of the Slovak koruna against the Czech koruna took place at the end of the currency union at the beginning of the year 1993. In the following years, SKK was depreciated down to CZK 72 to 80 per SKK 100.

As a result of the different policies, the level of wages, which had been practically identical in the common state, grew wide apart. The average monthly nominal wages reached CSK 4,667 in the Czech Republic and CSK 4,519 in the Slovak Republic in the year 1992 (see FSU 1992 and CSU 1993). In the year 2007, the nominal wages in the Czech Republic reached EUR 781 and in Slovakia it was EUR 597 (exchange rate adjusted), so the difference increased from 3\% to 30\% (see Podkaminer, Pöschl et al. 2008, pp. 144-145). Czech economy achieved the fastest growth of real wages among all transforming countries. In the year 2005 , wages increased by $38 \%$ here compared to the level before transformation, while in Hungary they grew by $19 \%$ and in Poland only by $2 \%$. In Slovakia, real wages did not reach the pre-transformation level until the year 2005, their decrease reaching approximately $3 \%$. Real wages in the Baltic countries, Bulgaria, Romania, Ukraine and Russia were also below pre-transformation level (see Klaus, Tomšík 2007, p. 43).

The adjustment of wages to the lower economic performance of Slovak economy following the dissolution of Czechoslovakia and the related division of economic policies led to a considerable increase in competitive ability.

An opposite example can be seen in the new Federal Lands of Germany, which obtained a major inflow of resources from the western Federal Lands after the reunification. From the fall of the Berlin wall until the year 2004, more than 1,25 trillion euro was transferred to the new Federal Lands, but their economic level did not equilibrate. GDP per capita stagnates at approximately $63 \%$ of the level in the more developed western part of Germany. Compared to the situation prior to the reunification, the economic level grew only slightly in Eastern Germany, and that was only due to a decrease in population (according to the report Berg et al., 2004).

Due to the conversion from eastern to western marks using the unrealistic 1:1 exchange rate, the citizens of the new Federal Lands "became rich" uncommonly fast, the price for this being the loss of competitive ability of the entire economy. With unchanged underlying productivity of labour and a sharp increase in wages, the unit labour costs (ULC) increased abruptly. In this situation, Western competitors easily disabled East-German companies. Mass unemployment developed, along with brain drain and flight of qualified labour. The westward rush of population thereby continued even after the reunification, reaching hundreds of thousands again (in total this involves more than a million people already). In the case of the previously divided Germany, the fundamental social changes following the fall of the Berlin wall brought about political interest in a fast equalisation of conditions, which became superordinated to economic rationality.

The common objective of the transformation process in Czech as well as Slovak economy was a fundamental change of production structure, which was only enforced with the abundant help of foreign investors. They financed the restructuring of 
production, corresponding to changes in demand abroad as well as at home, and helped find new markets. In both economies, a somewhat one-sided focus on the manufacturing has developed especially the automotive industry and the electrical industry. In Slovakia, where three foreign car manufacturers has already operated (Volkswagen in Bratislava, Kia in Žilina and SPA Peugeot in Trnava), the total capacity of production reaches 850,000 cars per year, so that there is one car per six inhabitants. In the Czech Republic, the total capacity is only slightly higher. 900,000 cars are being produced here, so that there is one car per eleven inhabitants (moreover a new plant of the car manufacturer Hyunday being built in Nošovice). A characteristic common trait of the production structure in both countries remains the ratio of services still lagging behind developed countries as well as the neighbouring new EU member states.

In both countries, agriculture has been considerably limited, its ratio in the gross value added having dropped to the current $2.6 \%$ (2006, current prices) and some significant elements of livestock production have even posted absolute decrease. Between the years 1989 and 2006, for example, meat production (in thousands of tonnes of live weight) decreased from 1,289 to 620 in the Czech Republic and from 593 to 544 in Slovakia. Milk production (in millions of litres) dropped from 4,893 to 2,694 in the Czech Republic and from 1,995 to 1,062 in Slovakia. ${ }^{11}$

The decrease in housing construction was fierce. In the middle of the $1980 \mathrm{~s}$, more than 100,000 apartments were being finished in Czechoslovakia every year (approximately 77,000 in the Czech Republic and around 38,000 in Slovakia) and in the year 1989, as the construction boom faded, 55,000 apartments were built in the Czech Republic and 33,000 in Slovakia. In the middle of the 1990s, only 13,000 apartments were being finished in the Czech Republic and 6,000 in Slovakia. From the year 2006, a certain increase occurred to 30,000 apartments in the Czech Republic and 14,000 in Slovakia. But even this favourable development represents only a fraction of the supreme housing construction in the 1980 s. $^{12}$

\section{Cost competitiveness}

A low wage level is the basis of cost/ price competitiveness of all new EU member states. Slovakia stands out especially, having the lowest nominal wages as well as labour costs per capita among all new member states. The Czech Republic has wages as well as the total labour costs per person nearly one third higher than Slovakia does, and the situation is similar in Hungary. Due to the not very big difference in labour productivity, ULC differ in a similar way, slightly exceeding one half of the EU-27 average in the Czech Republic, while in Slovakia they only reach $40 \%$ in this comparison (see Table 5).

11 See FSU (Federal Statistical Office), CSU (Czech Statistical Office) and SSU (Slovak Statistical Office), (1992), pp. 54 and 70, CSU (2007) and SSU (2007).

12 See FSU, CSU and SSU (1992), p. 226, CSU (2007) and SSU (2007). 
Table 5

Labour Productivity and Nominal Unit Labour Costs in EU-5, 2007 (EU-27=100)

\begin{tabular}{|l|c|c|c|}
\hline & $\begin{array}{c}\text { GDP per employed } \\
\text { person (PPS) }\end{array}$ & $\begin{array}{c}\text { Nominal labour costs } \\
\text { per employee (EUR) }\end{array}$ & Aggregate ULC \\
\hline Czech Republic & 71.9 & 37.9 & 52.7 \\
\hline Slovakia & 75.2 & 30.3 & 40.3 \\
\hline Hungary & 73.0 & 40.0 & 54.8 \\
\hline Poland & 66.9 & 28.1 & 42.0 \\
\hline Slovenia & 84.7 & 63.6 & 75.1 \\
\hline
\end{tabular}

Source: 1) Eurostat (2009b), 7. 1. 2009; 2) Podkaminer, Pöschl et al. (2008), p. VI; own calculations.

Low ULC in Slovakia represents the basis of its high price competitiveness within Europe. This factor is more important than others, on which more attention often focuses in analyses (for example the level of corporate taxes, etc.). The labour productivity, measured by GDP per employed person, slightly exceeded the level in the Czech Republic in the year 2007. The persisting considerable difference in the economic level ensues from higher unemployment and is to some extent also influenced by demographic factors (lower percentage of citizens in non-productive age).

Within the Union, only Latvia, Lithuania, Romania and Bulgaria have lower nominal wages and total labour costs per employed person. Compared to all the above countries, Slovakia has a higher labour productivity, so that the unit labour costs are the lowest here within the entire EU-27 (with the exception of Bulgaria). Thanks to low unit labour costs, Slovakia has achieved the necessary competitiveness and dynamics and has become exceedingly attractive for the inflow of foreign capital.

The prevailing sources of competitive advantage in the Czech Republic and Slovakia are based on low wage and total costs and on taking over foreign technologies. These factors encourage an inflow of capital in search for cheap labour. This kind of prevalent focus does not offer good prospects, however. Compared to Asian low-cost economies, especially China (but also compared to the newly acceded Bulgaria), costs are relatively high here, ${ }^{13}$ while the fast developing Asian countries also progress to higher levels of technological intensity.

13 Compared to Austria, nominal wages in China reached approximately $7 \%$, in the Ukraine and Bulgaria $7 \%$ to $8 \%$ and in Romania $15 \%$ (in exchange rate conversion). In relation to Chinese wages, Czech wages as up to four times higher and Slovak wages are three times higher (the relation to Austrian wages reaches $28 \%$ in the Czech Republic and 21\% in the Slovak Republic). The unit labour costs, calculated as nominal labour costs in rate conversion, related to GDP per employed person in PPS, can be estimated in relation to Austria at $24 \%$ in Bulgaria and $49 \%$ in Romania, while in Slovakia they reach $37 \%$ and in the Czech Republic it is $44 \%$. While Romania has lower labour cost per employee than the EU-5 countries, it is lagging behind in productivity of labour far more, as a result of which the ULC are higher here than in the compared countries (see Podkaminer, Pöschl et al. 2008). 


\section{Acceleration of economic growth after EU accession}

The accession to the EU, accompanied by a cultivation of the institutional environment, has made Czech as well as Slovak economy more attractive for foreign capital and accelerated economic growth considerably. The average annual GDP growth per capita accelerated from $3.1 \%$ in the years $2000-2003$ to $5.6 \%$ in the years $2004-2007$ in the Czech Republic, and from $3.6 \%$ to $7.5 \%$ (in the year 2007 up to $10 \%$ ) in the Slovak Republic. Within the Visegrad Four (VS-4), GDP growth in Slovakia was the fastest in the past 15 years. Thanks to its dynamic growth, the fastest in the EU, Slovakia is being referred to as Europe's economic tiger. Due to a recession in the second half of 1990s, economic growth in the Czech Republic slowed down and acceleration only came in the current decade (see Figure 3).

Figure 3

GDP Rate of Growth in VS-4 Countries and in EU-15, 1993-2007 (in \% of constant prices, $1992=100)$

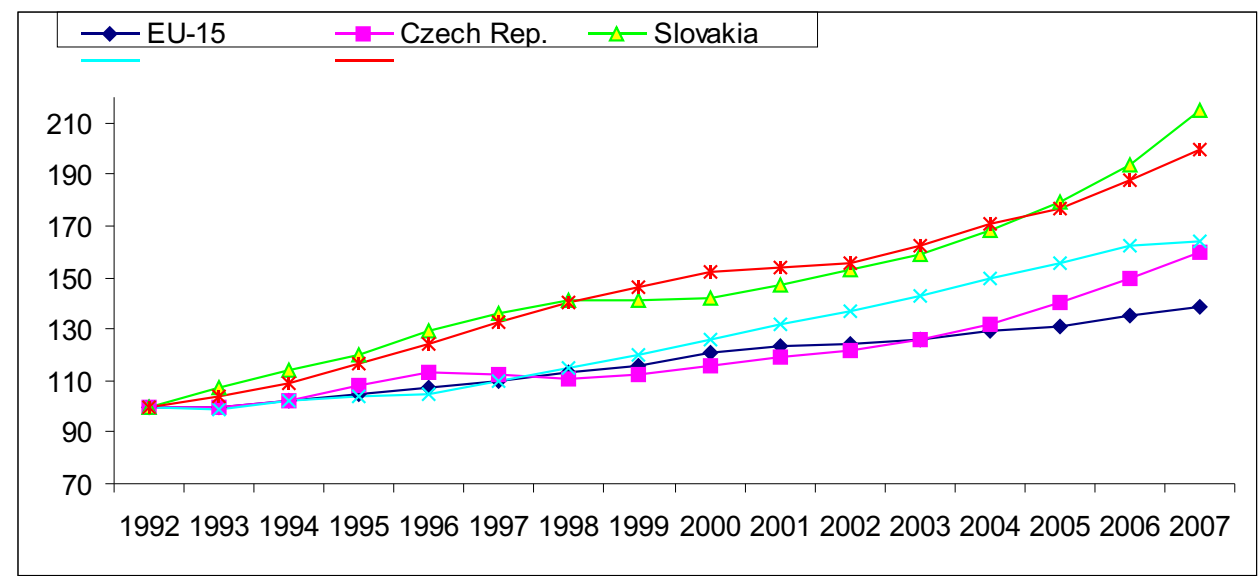

Source: Eurostat (2009b), 10. 2. 2009; own calculations.

Even with the extraordinarily high GDP growth rates, high unemployment persists in Slovakia. Although the rate of unemployment decreased to $11.1 \%$ in the year 2007 (from 18 to $19 \%$ in the years 2001-2004, according to the Labour Force Sample Survey), its level remains the highest among the EU-27 countries. Strong regional differences in the rate of unemployment are also a negative phenomenon. The rate is low in the West-Slovakian districts, while it remains high in Central and Eastern Slovakia. ${ }^{14}$ In the Czech Republic, unemployment has dropped to 5.3\% in the year 2007, which is considerably below the EU-27 average (7.1\%) and is among the lowest among the new

14 In the year 2006, with nationwide unemployment of $13.4 \%$, its rate reached from $4.3 \%$ to $8.8 \%$ in the western Slovak regions of Bratislava, Trenčín and Trnava, while in the regions of Prešov, Košice and Bánská Bystrica it reached from 18.1\% to 21.1\% (according to the Labour Force Sample Survey). 
member states. ${ }^{15}$ High unemployment in Slovakia encourages strong labour migration to the Czech Republic, which reaches tens of thousands of people. The migration involves both low-qualified labour and specialists in highly qualified professions. The current robust economic growth in Slovakia can be expected to narrow down the gap between wages and reduce the pressure on outflow of labour in future.

The boom of foreign direct investment (FDI) was somewhat delayed in Slovakia, as a result of the political development. In the Czech Republic, net inflow of foreign direct investment reached 10\% of GDP at the end of the 1990s already, while in Slovakia such high values were not achieved until the beginning of the current decade. In the years 2000 to 2006, net FDI inflow represented less than 7\% of GDP here. The effects of the accelerated inflow currently co-operate to the positive effects of integration processes after accession to the EU and the adopted radical economic reforms. Due to Slovakia coming from a lower economic level, the intensity of taking over technologies from the more developed countries implies faster pace of catching up.

\section{Real convergence and its factors}

The considerable lead in the rates of economic growth on the average rates in EU countries, which settled in at the turn of the millennium in both monitored economies, was reflected in the approximation of their economic levels to the developed countries. In the current decade, Slovakia as well as the Czech Republic belongs among the fastest converging countries within the Central-European five (EU-5). ${ }^{16}$ The gap compared to the EU average narrowed down by 13 percentage points in the Czech Republic and by 18 percentage points in Slovakia between the years 2000 and 2007. The Czech Republic overtook the level in Portugal and Malta, advancing to $17^{\text {th }}$ place among the EU-27 in terms of GDP per capita in purchasing power standards (PPS), ${ }^{17}$ Slovakia finds itself in the $21^{\text {st }}$ place before Hungary, Lithuania, Latvia, Poland, Romania and Bulgaria (see Figure 4). ${ }^{18}$

15 In the Czech Republic, too, regional differences exist. The highest rate of unemployment involves areas with previous concentration of heavy industry. In the year 2006, with a nationwide average of $7.1 \%$, the rate of unemployment reached $12.0 \%$ in the Moravia-Silesia and $13.7 \%$ in the Ústí region (according to the Labour Force Sample Survey).

16 The new Central European member states referred to as the EU-5 include the Czech Republic, Hungary, Poland, Slovakia and Slovenia.

17 The purchasing power standards (PPS) are artificial units of the common currency on the basis of the euro, based on the average prices in a group of member states (in the given case the EU-27).

18 As the volume indices based on purchasing power parities are not sufficiently accurate to establish a precise ranking of countries, the OECD classifications divide countries into several groups according to their GDP per capita (see OECD, 2008): high income (with GDP p.c. $125 \%$ and more in relation to the average), high middle (100-124\%), middle (75-99\%), low middle (50-74\%), low (25-49\%) and very low (less than $25 \%$ ). Economies with very low GDP per capita do not occur among EU countries (in Europe, they include Albania, Bosnia and Herzegovina, Moldavia and Ukraine). 
Figure 4

GDP per capita in PPS, $2007(E U-27=100)^{1)}$

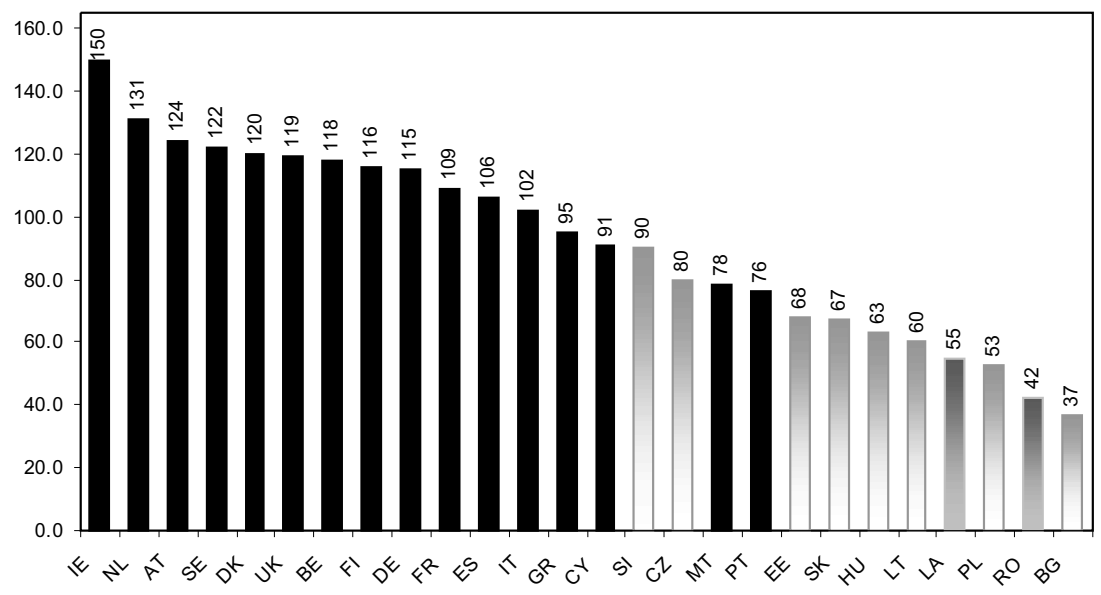

1) Luxembourg $=267$.

Source: Eurostat (2009b), 10. 2. 2009.

In mutual relation, in the first half of the 1990s, the economic level of Slovakia receded from that in the Czech Republic, and then returned to the starting position, and in the current decade, expeditious catch-up takes place. In the year 2007, Slovakia already achieved $84 \%$ of the level of the Czech Republic in terms of GDP per capita in PPS (see Figure 5 and Table 6).

Figure 5

Relation of GDP per capita in Slovakia to the Czech Republic, 1992-2007(in PPS, CZ $=100)^{1)}$

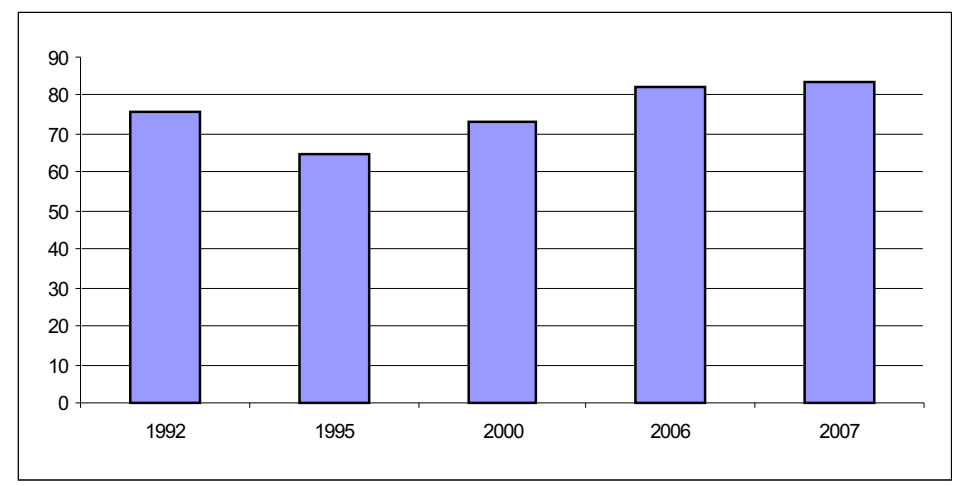

1) Current prices and current parities. 1992 in Czechoslovak korunas, other years in purchasing parity standards (PPS).

Source: CSU (1993, 1996); Eurostat (2009b), 10. 2. 2009; own calculations. 
Table 6

GDP per capita in the Czech Republic and in Slovakia, 1992-2007

\begin{tabular}{|l|r|r|r|r|r|}
\hline & $\mathbf{1 9 9 2}^{\mathbf{1}}$ & $\mathbf{1 9 9 5}$ & $\mathbf{2 0 0 0}$ & $\mathbf{2 0 0 6}$ & $\mathbf{2 0 0 7}$ \\
\hline $\begin{array}{l}\text { Thousands PPS }(\boldsymbol{C S K})^{2)} \\
\text { Czech Republic }\end{array}$ & 76.7 & 10.8 & 13.0 & 18.3 & 20.0 \\
\hline Slovakia & 58.1 & 7.0 & 9.5 & 15.0 & 16.7 \\
\hline SK in \% to CZ & 76 & 65 & 73 & 82 & 84 \\
\hline $\begin{array}{l}\text { In \% to EU-27 } \\
\text { Czech Republic }\end{array}$ &.. & 74.0 & 68.5 & 77.4 & 80.2 \\
\hline Slovakia &.. & 47.9 & 50.1 & 63.5 & 67.0 \\
\hline
\end{tabular}

1) 1992 in Czechoslovak korunas, other years in PPS. 2) Current prices and current parities.

Source: Auer, Müller (1993); CSU (1993, 1996); Eurostat (2009a), 10. 2. 2009; own calculations.

Upon the whole, in the past 15 years since the dissolution of the common state, GDP per capita in constant prices grew 1.6 times in the Czech Republic and doubled in Slovakia. In addition to this key indicator, characterising the growth of the volume of products in domestic constant prices, the economic level in international comparison also reflects the success in trade with the outside world.

It is the development of terms of trade ( $\mathrm{T} / \mathrm{T}$, that is the relation between prices achieved in export and import), which reflect the change of the quality parameters of the economy. In the Czech Republic, T/T improved by $25 \%$ over the past 15 years thereby contributing to the convergence of economic level to advanced EU countries. In Slovakia, on the contrary, they deteriorated by $6 \%$, which impeded the catching of economic level. This phenomenon is related to a different development of the nominal exchange rate of CZK and SKK, especially in the 1990s. In the current decade, the rates of both currencies appreciate, though with different intensity. The real gross domestic income (RGDI), which reflects the development of terms of trade, developed faster than the GDP in the Czech Republic, while in Slovakia it was vice versa (see Table 7).

Table 7

GDP and RGDI per capita Rates of Growth, 2001-2007 (in \%, annual averages)

\begin{tabular}{|l|c|c|c|}
\hline & GDP & RGDI & Difference in p.p. \\
\hline Czech Republic & 4.4 & 4.9 & 0.5 \\
\hline Slovakia & 6.2 & 5.6 & -0.6 \\
\hline EU-27 & 1.7 & 1.8 & 0.1 \\
\hline
\end{tabular}

Source: Eurostat (2008a, 2008b), ECFIN (2008), pp. 30-31, 80-83; own calculations.

The frequently accentuated lead in the rates of GDP growth in Slovakia compared to the Czech Republic fades to a large extent in the RGDI indicator. The GDP per capita of Slovakia grew 1.8 percentage point faster in the most recent decade than was the case in the Czech Republic, whereas in the rates of RGDI per capita growth, the difference reached only 0.7 percentage points. The difference between GDP and RGDI is significant in small open economies. In the European Union as a whole, the development of the two indicators is identical and making a distinction between them is not as necessary. 


\section{Price convergence}

Compared to the EU average, the comparative price level (CPL) in Slovakia, similarly to Hungary and Poland, approaches the relation in economic level (measured by GDP per capita). A characteristic feature of the Czech economy is the persisting relatively great downwards deviation of the price level from the economic level. In the period from the year 1995, there has been a fast increase in CPL, while it is still below the levels corresponding to a country with the given economic level. In relation to the EU-15, GDP per capita in PPS reached $72 \%$ in the year 2007, while the comparative price level of the total GDP reached only 59\%. Slovenia differs in that the price level there does not grow in relation to the EU-15, but stagnates or decreases slightly, as it was relatively high in the starting period (see Figure 6).

Figure 6

Comparative Price Level and Economic Level in EU-5 countries, 1995-2007 (EU-15 = 1)

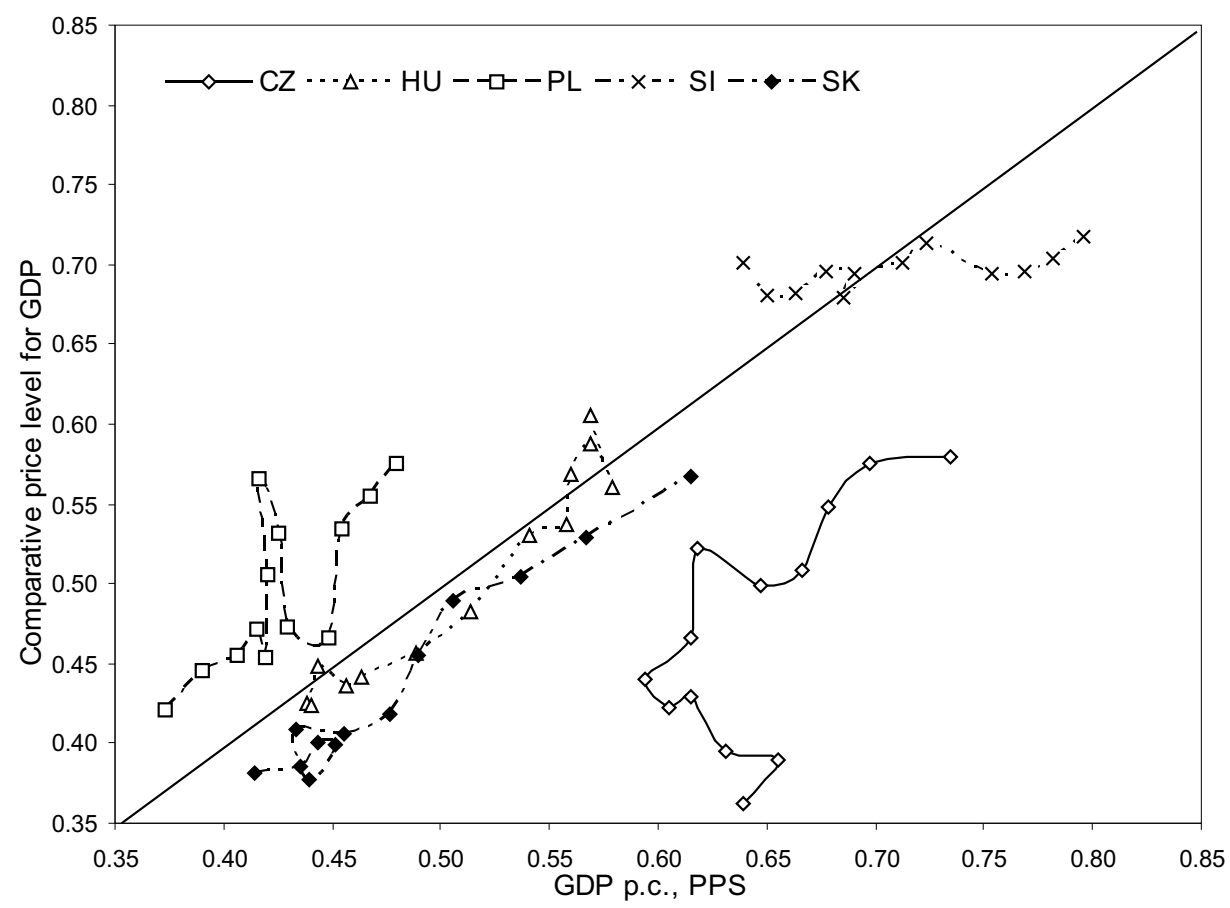

Source: Vintrová, Žd'árek (2007, p. 16); Eurostat (2008a), 7. 8. 2008; own calculations.

The situation is different when comparing with the U.S., where the comparative price level has decreased sharply after the depreciation of USD. Compared to the U.S., the relation of price level is much above the relation in the economic level in all EU-5 countries. In the Czech Republic there was lower only in the starting period (see Table 8). 
Table 8

CPL and Economic Level in EU-5 in Relation to USA, 1995 and 2007 (USA = 100)

\begin{tabular}{|l|c|c|c|c|c|c|}
\hline \multicolumn{2}{|c|}{} & Czech Rep. & Hungary & Poland & Slovenia & Slovakia \\
\hline \multirow{2}{*}{ GDP p.c. } & 1995 & 46.4 & 31.8 & 27.0 & 46.8 & 30.0 \\
\cline { 2 - 7 } & 2007 & 52.5 & 41.1 & 35.0 & 58.4 & 43.9 \\
\hline \multirow{2}{*}{ CPL } & 1995 & 41.7 & 48.9 & 48.5 & 80.6 & 43.9 \\
\cline { 2 - 7 } & 2007 & 70.3 & 73.5 & 69.4 & 87.5 & 69.4 \\
\hline
\end{tabular}

Source: Eurostat (2008a), (2008b), 31. 12. 2008, own calculations.

The fast price level convergence in the Czech Republic to countries of the EU was taking place entirely by CZK nominal exchange rate appreciation in the current decade. In the years 2001 to 2007, the average annual appreciation of CZK against EUR reached $3.6 \% .{ }^{19}$ The inflation differential had been negative in the same period. The average annual rate of inflation reached $2.2 \%$ in the euro area, while in the Czech Republic it was only $2.1 \%$. In Slovakia inflation was considerably higher; it reached $5.1 \%$ in annual average. The positive inflation differential on the euro area reached 2.9 p.p. (see Table 9). The price convergence of Slovakia took place both via the inflation channel and an appreciation of the nominal exchange rate. The exchange rate channel prevailed a little, as the average annual appreciation of SKK on EUR reached 3.4\% in 2001-2007.

Table 9

Inflation Rate and Differentials to the Euro Area in the Czech Republic and Slovakia, 1997-2007 (HICP) $)^{1)}$

\begin{tabular}{|l|c|c|c|c|}
\hline & $\mathbf{1 9 9 7 - 2 0 0 7}$ & $\mathbf{1 9 9 7 - 2 0 0 0}$ & $\mathbf{2 0 0 1 - 2 0 0 7}$ & $\mathbf{2 0 0 7}$ \\
\hline $\begin{array}{l}\text { Inflation rate (in \%) } \\
\text { Czech Republic }\end{array}$ & 3.5 & 5.8 & 2.1 & 3.0 \\
\hline Slovakia & 6.4 & 8.8 & 5.1 & 1.9 \\
\hline Euro area & 1.9 & 1.5 & 2.2 & 2.1 \\
\hline $\begin{array}{l}\text { Inflation differentials (in p.p.) } \\
\text { Czech Republic }\end{array}$ & 1.6 & 4.3 & -0.1 & 0.9 \\
\hline Slovakia & 4.5 & 7.5 & 2.9 & -0.2 \\
\hline
\end{tabular}

1) $\mathrm{HICP}=$ harmonized index of consumer prices.

Source: Eurostat (2008b), 31. 12. 2008.

The performance changed considerably in the Czech Republic in 2008. Due to the government reforms (changes in VAT and excises rates and in regulated prices of energy and housing) the inflation rate reached $6.3 \%$ in the annual average and far exceeded the $3.3 \%$ rate in the euro area (HICP). The appreciation of CZK continued in the same time

19 At the same time, the foreign trade balance did not deteriorate and passed into the active from the year 2005 . 
and reached enormous highs. ${ }^{20}$ The CZK became the fastest appreciating currency in the world up to July 2008, when the tendency changed to depreciation again. The gap between the CPL and economic level underwent a flat decrease and so the economic foundation of a fast currency appreciation was exhausted. The cost competitiveness of the Czech economy descended. In Slovakia, the appreciation of SKK was also relatively high in the first half of 2008, what was connected with the rising interest of investors to the stabilised Central European region in this time. ${ }^{21}$ However, the rate of inflation $(3.9 \%)$ was nearer to the euro area average and the Slovak CPL does not increase so quickly as in the Czech Republic.

\section{The different balance of costs and benefits of the euro adoption}

The persisting tendency towards currency appreciation needs to be taken into account during the transfer to the common currency, after the exchange rate channel is dropped and the price level convergence takes place via the inflation channel.

The question of the euro adoption cannot be narrowed down to the fulfilment of the Maastricht criteria alone, the fulfilment of which is necessary to ensure stability of the common currency. In addition to this, it is also necessary to consider one's own interests and criteria, especially the benefits for economic growth and for the economic level convergence to advanced countries. Early adoption of the common currency in the in the catching-up economies has its advantages as well as disadvantages.

In the Czech Republic, the disadvantages are being accentuated with respect to the loss of the country's own exchange rate adjustment mechanisms in the stage of incomplete real convergence and non-harmonised economic cycles. According to all signs, the long-term tendency towards appreciation of the CZK has not yet been fully exhausted. (However, the development in 2008 has strongly eroded these arguments, as the great deviation of the exchange rate from the purchasing power parity within the EU has fallen substantially.)

The exchange rate channel has a number of advantages, which vary according to the different interest groups. In addition to the pressure on lower inflation and stabilisation of inflation expectations, it is for example the appreciation of financial assets (denominated in the local currency) in relation to abroad over time. If, in case of an absence of the exchange rate channel and the inability to appreciate the currency, price convergence is only ensured by a higher inflation, monetary reserves denominated in CZK will be depreciated fast. If the koruna were undervalued against the euro, a devaluation of financial savings, pensions and other koruna claims would occur in case of premature adoption of the euro.

The Slovak Republic is currently extending its integration into the EU to the realm of the currency. As the only one among the Visegrad countries, it has been part of the

20 The average annual exchange rate was $24.94 \mathrm{CZK/EUR} \mathrm{in} \mathrm{2008,} \mathrm{while} \mathrm{in} 2007$ it was 27.76 CZK/EUR. The annual appreciation reached $11 \%$ and far exceeded the trend highs.

21 In the first 6 months of 2008 the CZK appreciated about $15 \%$, SKK about $11 \%$, PZL about $12 \%$ and HUF about $10 \%$. All the central European currencies depreciated very quickly in the second half of 2008 and on the beginning of 2009 , on the contrary. 
European Exchange Rate Mechanism (ERM II) since the end of the year 2005 already $^{22}$ and has been preparing for adoption of the euro as of 2009. After having joined the ERM II, it was necessary to reduce inflation, so that the Maastricht criteria for adoption to the euro area would be fulfilled. In the year 2006, inflation reached $4.3 \%$ and in the year 2007 it decreased further to $1.9 \%$ (annual average according to HICP). ${ }^{23}$

The Slovak koruna continued to appreciate further while being part of ERM II. In order not to exceed the upper band above the permitted $15 \%$, two preventive revaluations of the central parity had to be undertaken. ${ }^{24}$ Some economists had seen the original central parity as undervalued from the beginning (see for example Iša, Okáli, 2008, p. 318). ${ }^{25}$

During the political decision-making in Slovakia, the views inclined to fast adoption of the euro, without any more serious discussion on this subject have preceded. According to a document of the Czech government entitled The Czech Republic's Updated Euro-area Accession Strategy, on the other hand, the original date has been postponed indefinitely (see Ministry of Finance of the Czech Republic, 2007). A more informed economic discussion did not stir up until after this decision (see for example the collective volume by Pečínková, ed., 2007).

If we compare the prerequisites for adoption of the common currency from the perspective of real convergence, Czech economy is closer to countries of the euro area in terms of being economically advanced. The GDP per capita in PPS reaches $73 \%$ here already compared to the euro area, while in Slovakia it is only $61 \%$ (data for the year 2007, see Eurostat 2008b). A greater gap between economic levels implies higher priority and greater urgency of catching up with the economic level of developed countries. The criteria for accession to the euro area, which are based on the conditions of economically advanced countries, do not create the prerequisites for this. A country's own monetary policy can react more flexibly to asymmetrical shocks and support the maintenance of fast economic growth.

Convergence of comparative price level progresses simultaneously with the economic level convergence. These relations are more balanced in the Slovak economy. In the Czech Republic, the price level departs significantly downwards from the economic level, so that longer suspension is necessary for their balancing (see Figure 6, higher up). ${ }^{26}$

The costs and benefits balance of the euro adoption finds itself in a somewhat different position in Slovakia than in the Czech Republic. In addition to the general

22 Slovakia joined ERM II as of November 26, 2005 with central parity of SKK 38.455 per one euro within a fluctuation band of SKK 30.1260 to SKK 40.7587 /EUR.

23 For the year 2008, the Slovak National Bank estimated a 2.8\% rate of inflation. However, the development of world prices (oil and foodstuff) made the achievement of this goal not realizable. The result was $3.9 \%$ according to HICP.

24 After the first shift of the central parity in the year 2007, new vehement appreciation of the Slovak koruna took place in the year 2008, prior to the approval of the accession of Slovakia to the Euro-area by European institutions.

25 In the year 2007, the central parity was revaluated to SKK 35.4424 per one euro with a fluctuation band from SKK 30.1260 to SKK 40.7587/EUR. At the time of setting the convergence rate (SKK $30.1260 /$ EUR) the central parity was revaluated again.

26 During the year 2008 these relations changed significantly, but the quantification is not yet finished. 
benefit of the removal of exchange rate risks on the main trade partners and reduction of the transaction costs, an important thing for Slovakia is the transfer to an environment with low interest level, which makes loans cheaper and supports investment and growth. This advantage does not apply to the Czech Republic, because interest rates are lower here than in the euro area and after the adoption of the euro, loans would become more expensive, on the contrary. The "euro umbrella", ensuring currency stability, also has greater importance for Slovakia. There are relatively high deficits of the current account of the balance of payments, which reached as much as $8 \%$ of GDP in the years 2005 and 2006. The risk of speculative attacks on the currency is therefore higher, not to mention the smaller scope of the economy. In the Czech Republic, the current account deficit reached between $1 \%$ and $2.5 \%$ of GDP in the same years.

Other benefits of fast adoption of the euro also come into question, such as acquiring the status of a stabilised economy and the disciplining influence on public budgets. (Some politicians look on the adoption of the euro as a matter of raising the political prestige and rating of the country.) Nevertheless, in the case of Finland, a member, and Sweden, a non-member, it has turned out that the adoption of the common currency did not have any principal effect on trustworthiness and good reputation of the economy. The by-passing of rules and use of "creative accounting" in Greece also showed that rules imposed from the outside do not contribute much towards budget discipline. ${ }^{27}$ For all the reasons mentioned, the particular balance of benefits and risks in the Czech Republic and Slovakia is not the same. It is therefore not only a matter of a different political approach, although that, too, certainly plays its role.

\section{Conclusions}

The fast drive of the economic level in Slovakia during the existence of a common state after the World War II represents a historically unique example at the given time. It was enabled by a corresponding economic policy focus and facilitated by the existence of central planning. The dissolution of Czechoslovakia did not interrupt the convergence of the economic levels of the two successor states. Even after the divorce, Czech and Slovak economies are close, and due to their historical links they find abundant opportunities for cooperation on the free EU market. Although Slovak economy lost a considerable inflow of resources from the economically more advanced part of the common state, it has been able to adjust to new market conditions by having significantly lowered the relative price level and depreciated the exchange rate of Slovak koruna more profoundly. It has thus attained high cost competitiveness within the EU. Thanks to a flexible adjustment to its own economic conditions, it has gained greater dynamics. After the initial sway, it began to quickly reduce the gap to the average EU economic level, and has been successfully catching up with the level of Czech economy.

The two countries are important mutual trade partners, with the highest proportion of import as well as export after Germany. Intensive movement of labour force continues

27 The Stability and Growth Pact holds even for non-members of the euro area, though in their case offence is accompanied by more lenient sanctions. 
to take place, which is nearly unilateral, from Slovakia to the Czech Republic, due to the differing rates of unemployment. Different economic policies and a different course of reforms provide the possibility for benefiting from mutual exchange of experience.

A temporary functioning of its own currency in the Czech Republic and the euro in Slovakia need not harm the development of mutual economic relations. Long-term duration of such a situation is not desirable, however. With a longer postponement of adoption of the euro, the risks of shocks from outside increase which cannot be faced up with a country's own monetary policy, and in case of transmission of a financial crisis, not even by a favourable development of the domestic fundamentals. This aspect, which the Optimum Currency Area Theory II refers to as waiting costs, has been neglected by discussion in the Czech Republic so far.

A common fundamental challenge awaits both countries in the future. With successful convergence of their economic level to the EU average, unavoidable exhaustion of the currently prevailing sources of competitive advantage takes place, which is based on low costs and taking over foreign technologies. A shift to qualitative sources of competitiveness becomes essential, which should focus on development of innovative abilities and on offering specific products and services of higher quality. It is otherwise not possible to stand ground in competition with low-cost countries, especially China.

Long-term prerequisites for such shift exist in the industrial traditions and qualifications, technical capability and relatively high level of learning in the population. These prerequisites need to be adjusted to new demands, though, emerging in knowledge-based economy. The transfer from prevailing cost competitiveness based on low wages to qualitative competitiveness applied in technologically more demanding and sophisticated products and services cannot get along without increasing the motivation towards further education and adjustment of qualifications, and without greater use of the country's own innovations.

\section{References}

Auer, J., Müller, W. (1993), "Bilaterale Wirtschaftsvergleiche mit Polen, Ungarn, ČSFR, Jugoslawien, Rumänien und Sowjetunion." Wien: Statistik Österreich, Statistische Nachrichten, 1993, Vol. 48, No. 8.

Berg, S., Hornig, F., Kurbjuweit, D., Martens, H., Reiermann, Ch., Repke, I., Röbel, S., Schimmöller, H., Steingart, G., Winter, S. (2004), "Tabuzone Ost." Spiegel, 2004, no. 15, pp. 24-41.

Čsú. Statistická ročenka. Different annual volumes. Praha: Čsú.

Čsú (1996), Mezinárodní srovnání HDP České republiky v rámci Evropského srovnávacího projektu 1993. Čsú, Zprávy a rozbory, Souborné publikace, March 1996.

čsú HDP, Annual National Accounts. www.czso.cz.

Dědek, O. (2006), "Rizika a výzvy měnové strategie k převzetí eura." Politická ekonomie, 54 (1), pp. 3-21.

ECFIN (2008), "Statistical Annex of European Economy." Autumn 2008. Brussels: European Commission, Directorate General ECFIN, 2008.

EUROSTAT (2004), "Purchasing Power Parities and Related Economic Indicators for the EU, Candidate Countries and EFTA, Data 1991 to 2003 including final results of the revision 1995-2000." Statistics in Focus, 2004, No. 37.

EUROSTAT (2004), "Purchasing Power Parities and Related Economic Indicators for the EU, Candidate Countries and EFTA." Statistics in Focus, 2004, No. 53. 
EUROSTAT (2008a), National Accounts. Eurostat 2008. http://epp.eurostat.cec.eu.int. EUROSTAT (2008b), Structural Indicators. Eurostat 2008. http://epp.eurostat.cec.eu.int. EUROSTAT (2009a), National Accounts. Eurostat 2009. http://epp.eurostat.cec.eu.int. EUROSTAT (2009b), Structural Indicators. Eurostat 2009. http://epp.eurostat.cec.eu.int. FSÚ (1985), Historická statistická ročenka ČSSR. Prague: FSÚ 1985.

FSÚ, ČSÚ, CESTAT, CANSTAT Statistical Bulletin. Prague: FSÚ, ČSÚ, different annual volumes.

FSÚ, Čsú, SŠú (1992), Statistická ročenka České a Slovenské federativní republiky 1992. Prague: SEVT, 1992.

Havlik, P., Holsner, M. et al. (2008), "Weathering the Global Storm, yet Rising Costs and Labour Shortages May Dampen Domestic Growth." The Vienna Institute for International Economic Studies. WIIW Current Analyses and Forecasts, 2008, No. 1.

Iša, J., Okáli, I. (2008), "Európska menová únia, optimálna menová oblas a možné dôsledky vstupu Slovenska do eurozóny." (European Monetary Union, Optimum Currency Area and Possible Effects of Slovakias's Joining the Euroarea). Politická ekonomie, 56 (3), pp. 318-344.

Klaus, V., Tomšík, V. (2007), Makroekonomická fakta české transformace. Brno: NC Publishing, 2007.

MINISTERSTVO FINANCÍ ČR (2007), Aktualizovaná strategie přistoupení České republiky k eurozóně. Praha: Ministerstvo financí ČR, 2007.

MINISTERSTVO FINANCí ČR (2008), Makroekonomická predikce České republiky. (Macroeconomic Prediction of the Czech Republic). Praha: Ministerstvo financí ČR, January 2008.

Morvay, K., Okáli, I. (2007), "Hlavné trendy vývoja hospodárstva Slovenska v roku 2006 a ich odhad v roku 2007." Ekonomický časopis/Economic Journal. 2007, No. 6, pp. 539-553.

SŠú (2003), Štatistická ročenka Slovenskej republiky 2003. Bratislava: SŠú, 2003.

SŠú (2007), Štatistická ročenka Slovenskej republiky 2007. Bratislava: SŠú, 2007.

Pečínková, I., ed. (2007), "Euro versus koruna. Rizika a přínosy jednotné evropské měny pro ČR." Brno: Centrum pro studium demokracie a kultury, 2007.

Podkaminer, L., Pöschl, J. et al. (2008), "The Big Boom is Over, but Growth Remains Strong and Inflation Calms Down." The Vienna Institute for International Economic Studies. WIIW Current Analyses and Forecasts, 2008, No. 2.

Šikula, M. (2007), "Slovenská ekonomika v zrkadle konkurencieschopnosti." Podniková revue, 2007, No. 11 , pp. 9-22.

Vintrová, R. (2006), "Historické předpoklady a reálné perspektivy konvergence České republiky k Evropské unii." Studie Národohospodářského ústavu Josefa Hlávky, No. 7, 2006.

Vintrová, R., Žd'árek, V. (2007), "Links between Real and Nominal Convergence in the New EU Member States: Implications for the Adoption of Euro." Ekonomický časopis/Economic Journal, 2007, No. 5, pp. 3-20.

Vintrová, R., Žd'árek, V. (2007), "Vztah reálné a nominální konvergence v ČR a nových členských zemích EU." Working Paper CES VŠEM, No. 8, 2007.

WIIW, VIENNA INSTITUTE FOR INTERNATIONAL ECONOMIC STUDIES (2007). WIIW Handbook of Statistics - Central, East and Southeast Europe (2007)."Vienna Institute for International Economic Studies, 2007. 